\title{
Implementation of Problem-based Learning Model to Enhance Students Learning Outcomes in Buffer Solutions Topic
}

\author{
Lousia Vionalisa Letlora ${ }^{2}$, Murtihapsari ${ }^{*}$, Christiana Niken Larasati ${ }^{1}$, Apriani Sulu \\ Parubak', Achmad Rante Suparman ${ }^{1}$, Putri Surbakti Sarera ${ }^{1}$, Thelma Aluman² and \\ Radite Yogaswara ${ }^{1}$ \\ ${ }^{1}$ Department of Chemistry Education, Faculty of Teacher Training and Education, University \\ of Papua, Jl. Gunung Salju, Manokwari, 98314, Indonesia \\ ${ }^{2}$ Adventist High School, Jl. Karya ABRI, Manokwari, 98314, Indonesia \\ ${ }^{*}$ E-mail: murtihapsari.kadarusman@gmail.com
}

Received: 24 September 2021; Accepted: 1 December 2021; Published: 31 December 2021

\begin{abstract}
This research aims to determine the improvement of the process and learning outcomes of the buffer solutions topic by applying the Problem-based Learning (PBL) model. This research is based on Classroom Action Research (CAR) takes place in two cycles, with several stages including planning, implementing, observing, and reflecting. Our present study used 17 students of natural science $11^{\text {th }}$ grade SMA Advent Manokwari. The data was obtained from teachers and students. The data collection method used cognitive learning outcomes and observation. The data analysis uses descriptive analytic techniques. Our findings showed that the application of the PBL model can improve the quality of the learning process on the buffer solutions topic; the application of the Problem-based Learning (PBL) learning model has increased from cycle I with an average grade of 65.36 and a percentage of passing grades of $41 \%$ and cycle II with an average grade of 83.66 and a percentage of passing grades of $88 \%$.
\end{abstract}

Keywords: classroom action research, learning outcomes, problem-based learning

DOI : https://doi.org/10.15575/jtk.v6i2.11862

\section{Introduction}

The Problem-based Learning (PBL) model can be applied to a particular subject and material. The application of PBL must be able to combine the stimulus. PBL presents students with contextual problems, thus stimulating students to learn and solve problems (Ardyanto et al., 2018). PBL can overcome the gap between theory and practice. PBL effectively stimulates interest in science, increases knowledge construction, and improves problem-solving skills at the secondary school level. Some of the reasons for using PBL in schools, among others: using real-life problems, active involvement, interdisciplinary learning, students making choices in education, and collaborative learning (Tan, 2003). The problems experienced by students in Papua and other places are different, so we need an appropriate model to integrate the problem and its solution. The results of the research conducted by Utami et al. (2018), stated that there was a significant difference in the use of the Problem-based Learning ( $\mathrm{PBL}$ ) learning model on students' cognitive learning outcomes and had an effect of $30 \%$.

Transformation in a person can be done through the education process to adjust to the environment. Generally, every change always encounters problems such as the low quality of education and human resources. The government has made efforts to improve the quality of human resources by improving the 
L. V. Letlora, Murtihapsari, C. N. Larasati, A. S. Parubak, A. R. Suparman, P. S. Sarera, T. Aluman \& R. Yogaswara

teachers' quality, implementing curriculum changes, improving the assessment system, learning methods, facilities, and appropriate infrastructure. Based on Pigai et al. (2019) reporting, the curriculum is arranged by the plan or objectives, considering schools' teaching and learning process. The government is always making changes and improving the 2013 curriculum to achieve quality education. The 2013 curriculum has been developed from the 2006 curriculum and has been applied in schools, but the main principles of this curriculum have not been applied in the learning process. Therefore, achieving quality learning depends on the ability and behavior of teachers in managing the learning process. Teachers are responsible of educating, teaching, guiding, and evaluating the school's learning processes.

One of the subjects studied by students in high school is chemistry (Suswati \& Triyanti, 2014). Chemistry is one of the fields of Natural Sciences that studies the structure, materials, and changes experienced by materials in natural processes and experiments (Badiee et al., 2012). Chemical studies are concepts and theories and the application of chemistry to life. Therefore, chemistry is classified as a complex subject for some high school students.

Based on the results of interviews conducted with students at Advent Manokwari High School, it was found that one of the chemistry topics that was considered difficult was a buffer solution. This topic contains abstract reactions and calculations that are difficult to understand and affect student learning outcomes (Supardi \& Putri, 2010). One factor that makes it difficult for students to understand these subjects is a lack of interest in learning chemistry, and the learning process is teacher-centered, so it tends to be boring. Applying the Problem-based Learning (PBL) learning model can improve student cognitive learning outcomes, where cognitive learning outcomes in the first cycle were $70.24 \%$ with enough categories and increased in the second cycle to $83.50 \%$ (Putri et al., 2015). Following the description above, the authors are interested in conducting Classroom Action
Implementation of Problem-based Learning Model to Enhance Students Learning Outcomes in Buffer Solutions Topic

Research entitled Implementation of Problembased Learning Model to Enhance Students Learning Outcomes in Buffer Solutions Topic. This study aims to determine the effect of using PBL learning models and calculate the percentage increase in student learning outcomes on the buffer solutions topic.

\section{Research Method}

There are six steps of the Problem-based Learning Model used in this study. (1) Formulate the problem; the teacher guides students to determine the problem to be solved in the learning process, even though the teacher has resolved the problem. (2) Analyze the problem; steps for students to critically review problems from various points of view. (3) Formulate the hypothesis; students can formulate various possible solutions according to their knowledge. (4) Collect the data; students can find and describe various information needed to solve problems. (5) Test the hypothesis; students' in formulating and drawing conclusions are by accepting and rejecting the proposed hypothesis. (6) Recommend the problem-solving; the steps of students describe recommendations that can be made according to the formulation of the results of hypothesis testing and conclusions.

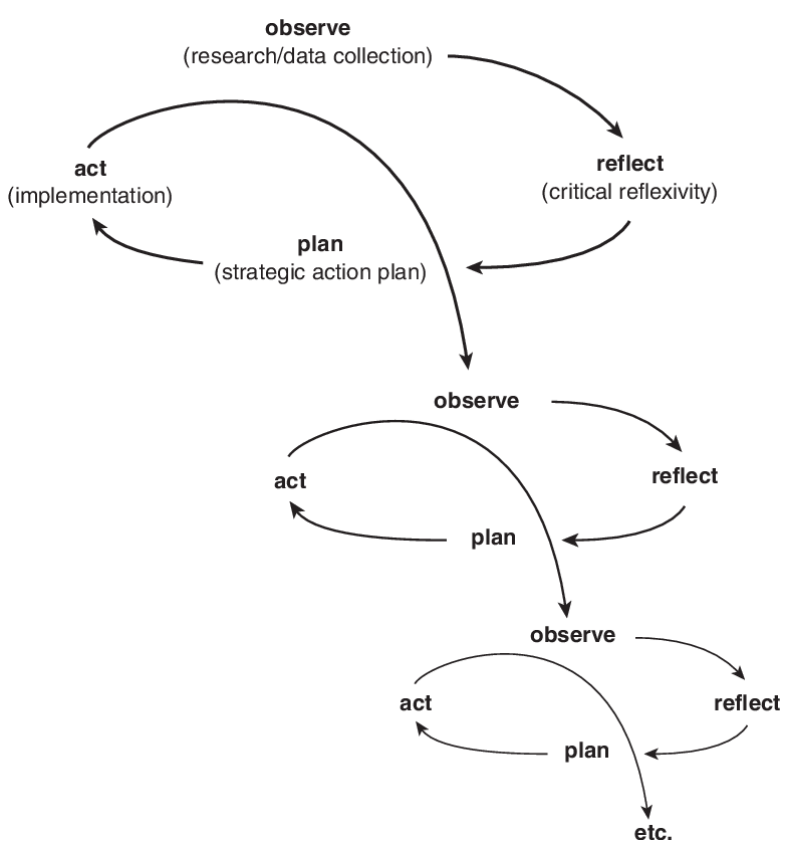

Figure 1. Hopkins Model

Jurnal Tadris Kimiya 6, 2 (December 2021): 185-194 
L. V. Letlora, Murtihapsari, C. N. Larasati, A. S. Parubak, A. R. Suparman, P. S. Sarera, T. Aluman \& R. Yogaswara

This Classroom Action Research uses the Hopkins model, which contains four components: planning, action, observation, and reflection (Beddu et al., 2018). The Hopkins model can be seen in Figure 1.

This research was conducted in two cycles, where each cycle will take place twice the learning process, as many as two sessions. An indicator of increasing student learning outcomes in each cycle is if the average value of the buffer solutions topic reaches a Minimum Completeness Criteria of 70 . As for data collection techniques through observation and tests of student cognitive learning outcomes, which are the total grade obtained by students, the average grade of students that can be calculated using Eq. 1, and the highest and lowest scores.

$$
\text { The average grade }=\frac{\text { the total grade of students }}{\text { the total of students }}
$$

The percentage of grades that exceed the minimum mastery criteria of students using the classic cognitive learning uses the Eq. (2):

$$
P=\frac{\text { Students that passed }}{\text { the total number of students }} \times 100 \text { (2) }
$$

In Eq. (2), $P$ is the percentage of cognitive learning that exceeds the minimum mastery criteria.

The percentage of grades that do not exceed the minimum mastery criteria uses the Eq. (3):

$$
P=\frac{\text { Students that did not pass }}{\text { the total number of students }} \times 100 \text { (3) }
$$

In Eq. (3), $\mathrm{P}$ is the percentage of cognitive learning that did not exceed the minimum mastery criteria (Aqib, 2010).

In this study, instruments in the form of multiple-choice tests were used as many as 50 numbers in the first cycle, then in the second cycle, multiple-choice test instruments as many as 50 numbers were used. Furthermore, the scores in cycle I and cycle II are compared to determine the increase in learning outcomes.
Implementation of Problem-based Learning Model to Enhance Students Learning Outcomes in Buffer Solutions Topic

The criteria for completeness of student learning outcomes can be said to be complete if the learning outcomes are $\geq 70$, can be seen in Table 1.

Table 1. Passing grade criteria of classical student learning outcomes

\begin{tabular}{clcc}
\hline No & Score & level of success & Category \\
\hline 1 & 5 & $\geq 85 \%$ & Very high \\
2 & 4 & $70 \%-84 \%$ & High \\
3 & 3 & $55 \%-69 \%$ & Moderate \\
4 & 2 & $40 \%-54 \%$ & Low \\
5 & 1 & $\leq 39 \%$ & Very Low \\
\hline & & & (Aqib, 2010)
\end{tabular}

The classification of categories and ranges of teacher and student observation scores can be seen in Table 2.

Table 2. Category and Observation Score Range for Teachers and Students

\begin{tabular}{cc}
\hline Value Range & Category \\
\hline $3.33<$ Score $\leq 4.00$ & Very good \\
$2.33<$ Score $\leq 3.33$ & Good \\
$1.33<$ Score $\leq 2.33$ & Sufficient \\
Score $\leq 1.33$ & Less \\
\hline & (Aqib, 2010)
\end{tabular}

\section{Result and Discussion}

This Classroom Action Research uses two cycles, in which each cycle has two sessions, and each session includes four stages: 1) Planning, 2) Implementation, 3) Observation, and 4) Reflection. This Classroom Action Research uses an integrated research pattern to study the problem (Suswati \& Triyanti, 2014).

Descriptive statistical analysis includes the average grade, the highest grade, the lowest grade, the percentage of passing and notpassing students in student learning outcomes and teacher teaching activities that use PBL learning models can be seen in Table 1. The assessment result of two observers on the average grade post-test average increased from cycle I of 65.36 to cycle II of 83.66, as shown in Table 3. 
L. V. Letlora, Murtihapsari, C. N. Larasati, A. S. Parubak, A. R. Suparman, P. S. Sarera, T. Aluman \& R. Yogaswara

Table 3. Student Learning Outcomes

\begin{tabular}{lllll} 
& \multicolumn{2}{c}{ Cycle I } & \multicolumn{2}{c}{ Cycle II } \\
\cline { 2 - 5 } $\begin{array}{l}\text { Average } \\
\text { Values }\end{array}$ & $\begin{array}{l}\text { Pre- } \\
\text { test }\end{array}$ & $\begin{array}{c}\text { Post- } \\
\text { test }\end{array}$ & $\begin{array}{l}\text { Pre- } \\
\text { test }\end{array}$ & $\begin{array}{c}\text { Post- } \\
\text { test }\end{array}$ \\
\cline { 2 - 5 } & 22.87 & 65.36 & 39.21 & 83.66
\end{tabular}

As for the stages of implementing this class action research activity as follows:

\subsection{Cycle I}

\subsubsection{Planning}

Before taking action, it is necessary to plan the day and time so that the implementation of the action can proceed according to a predetermined schedule, then prepare the tools that will be used during the implementation such as lesson plans, pre-test, and post-test questions, observation sheets and student worksheets.

\subsubsection{Implementation}

The implementation of the action in the first cycle was carried out twice as many sessions with sub-topics Introduction, properties, and composition of buffer solution for $3 \times 40$ minutes. When the action is in progress, other teachers and students who act as observers will assess the teacher's activities and students during the learning process.

\subsubsection{Observation}

The observation results of teacher activities at the first session obtained proper criteria in aspect number three, with a value of 4 . In this case, the teachers formed a group. Aspects number one and four get a score of 3 , and aspect five gets 2.5. While aspects number two, six, and seven got a score of 2 . Based on the results of the first session's average score, proper criteria were obtained with a score range of 2.64. this result is in line with the research conducted by Hulu (2020).

Based on the implementation of the second session's actions, an average score of 2.78 was obtained. Both sessions have increased, and they are in a suitable category in every aspect. The score is consistent with Hulu (2020) stated that the average score in the range of values of 2.42 and 2.85 is a good category. The mean scores of pre-test and post-test of students in
Implementation of Problem-based Learning Model to Enhance Students Learning Outcomes in Buffer Solutions Topic

the first cycle were 22.87 and 65.36, respectively. There is an increase in learning outcomes by 42.49 when seen from the difference in the pre-test and post-test scores in cycle I (Larlen, 2012).

Tabel 4. Minimum Mastery Criteria of Cycle I

\begin{tabular}{|c|c|c|}
\hline \multirow{2}{*}{ Completeness } & \multirow{2}{*}{$\begin{array}{l}\text { Amount of } \\
\text { Students }\end{array}$} & Cycle I \\
\hline & & Post-test \\
\hline Did not pass & 10 & $59 \%$ \\
\hline Passed & 7 & $41 \%$ \\
\hline Total & 17 & $100 \%$ \\
\hline
\end{tabular}

Table 4 explains that 17 students followed the learning process in cycle I. After applying the PBL learning model in the class, the average grade of learning outcomes of 7 students, which equates to $41 \%$, met the Minimum Mastery Criteria, while the other ten students, which equates to $59 \%$, did not achieve the Minimum Mastery Criteria. Students were required to understand the problem in the form of questions given by the teacher to solve them in groups actively.

Figure 2 shows that the average post-test score of students who passed the study on the buffer solutions topic was $41 \%$ lower than those who did not complete the study, which was $59 \%$ of the students. The results of this study are in line with what has been reported (Fitria et al., 2019). However, the percentage of students who have finished learning in this study is still low compared to those conducted using the same method, $51 \%$.

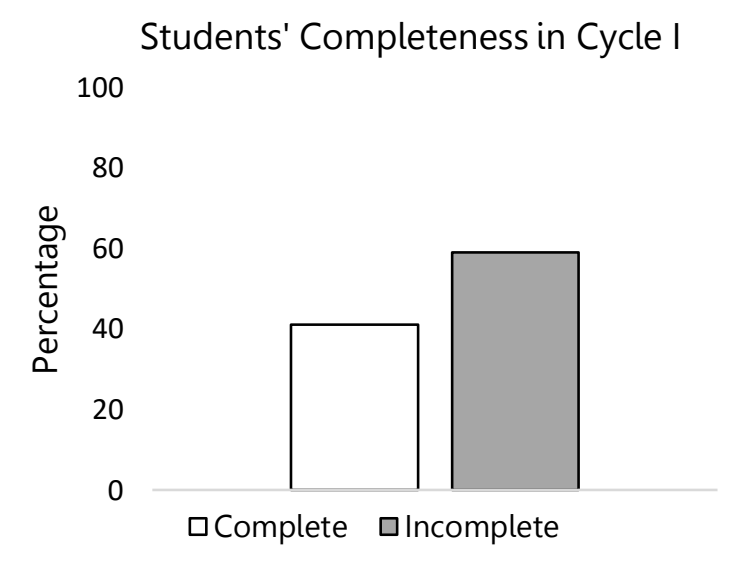

Figure 2. Percentage of Students' Meeting the Minimum Mastery Criteria in Cycle I 
L. V. Letlora, Murtihapsari, C. N. Larasati, A. S. Parubak, A. R. Suparman, P. S. Sarera, T. Aluman \& R. Yogaswara

\subsubsection{Reflection}

After taking action in cycle l, it can be seen that there are several aspects of the observation sheet that have a low score; this low score category can be described as follows:

\subsubsection{Teacher's activities}

In the first session, three aspects needed improvement: first, the teacher only explained the learning material without conveying the learning objectives during the learning process. Second, teachers do not guide students while learning, so students have a little difficulty summarizing the results of their discussions, and the third at the end of the session, the teacher does not provide motivation to students so that they are more active in learning. Then, in the second session, two aspects need to be improved: first, the teacher's presentation activity is not directing students to explain the discussion results (Asyhariyah, 2018).

\subsubsection{Student's activities}

In the first session, there were four aspects of correction; the first is that the students do not respond well to the delivery of the teacher at the beginning of learning. Second, students listening to the learning objectives do not understand the studied subject. Third, students cannot answer the questions well during the presentation. Fourth, students cannot make reasonable conclusions from the discussion results. This is slightly different in the second session, where the seven aspects include the teacher greeting, attendance, apperception, and motivation; conveying learning objectives and explaining learning materials; forming groups; discussing in groups; directing students; guiding students; closing the lesson. These observed aspects meet the exact criteria (Listiana et al., 2017).

Because the percentage of students who did not pass the study was higher than those who passed the study, it can be said that the results have not yet reached the grade of the minimum mastery criteria, and action needs to be improved in the second cycle (Mustofa et al., 2016).
Implementation of Problem-based Learning Model to Enhance Students Learning Outcomes in Buffer Solutions Topic

\subsection{Cycle II}

Learning activities will continue to cycle II to correct the shortcomings in cycle I regarding teachers' and students' cycle I regarding the teachers' and students' activities in the hope that there will be an improvement in learning outcomes in cycle II.

\subsubsection{Planning}

In the planning phase of the second cycle, the researcher prepares an instrument in the form of a syllabus, lesson plan, and subject matter so that it can be used by the teacher when teaching in class, and then the researcher explains the procedures for implementing the PBL model to the students so that the teacher can apply it during learning.

\subsubsection{Implementation}

The implementation of the action in the second cycle was carried out two times with the topic of the principle of buffer solution and the calculation of the buffer solution's $\mathrm{pH}$.

\subsubsection{Observation}

Observation results showed that both teacher's and student's activities at the third and fourth sessions in the second cycle showed perfect value criteria on the seven aspects with an average of 3.71. Hulu (2020) said that the value of 3.71 is included in the excellent category. Observation of the teacher's activeness at the fourth session showed that all seven aspects received an average score of 3.92 (Rauf \& Kusmanto, 2018). Student activity in the second cycle increased from the third session to the fourth session, as indicated by the average score of 3.85. Thus, the third and fourth sessions in the second cycle can have been achieved with satisfactory results in terms of teachers' and students' activities.

Tabel 5. Student Minimum Mastery Criteria in Cycle II

\begin{tabular}{|c|c|c|}
\hline \multirow{2}{*}{ Completeness } & \multirow{2}{*}{$\begin{array}{l}\text { Amount of } \\
\text { Students }\end{array}$} & \multirow{2}{*}{$\begin{array}{c}\text { Cycle II } \\
\text { Post-tes }\end{array}$} \\
\hline & & \\
\hline Did not pass & 2 & $12 \%$ \\
\hline Passed & 15 & $88 \%$ \\
\hline Total & 17 & $100 \%$ \\
\hline
\end{tabular}


L. V. Letlora, Murtihapsari, C. N. Larasati, A. S. Parubak, A. R. Suparman, P. S. Sarera, T. Aluman \& R. Yogaswara

Table 5 shows that 15 students, which equates to $88 \%$, passed their study in cycle II and met the Minimum Mastery Criteria grade. In contrast, two students which equates to $12 \%$ of the students did not pass the study.

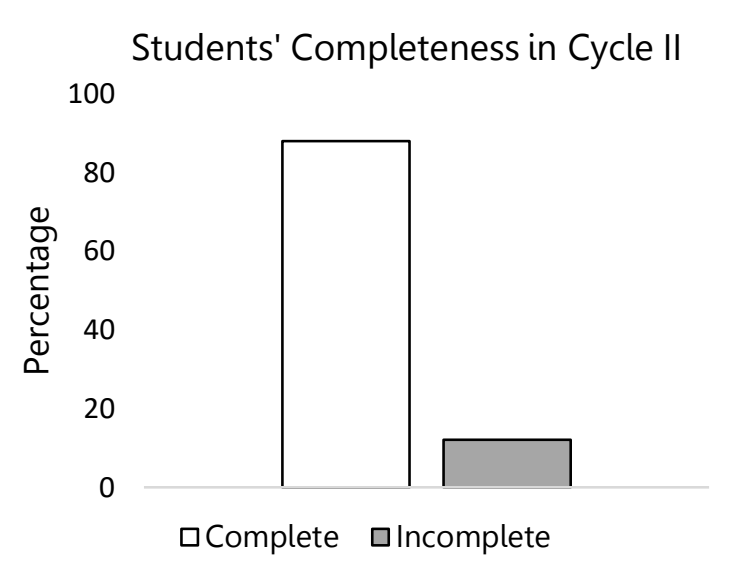

Figure 3. Percentage of Students' Meeting the Minimum Mastery Criteria in Cycle II

Student learning outcomes in cycle II experienced a significant increase compared to cycle I. The value of post-test passing percentage in cycle II increased to $88 \%$, and $12 \%$ of students did not pass, as shown in Figure 3. These results are in line with those reported by Fitria et al., (2019), where the results obtained in this second cycle fall into the high category.

\subsubsection{Reflection}

The increase in cycle II can be seen from the average value of teachers' observations in the first cycle at the first and second sessions of 2.64 and 2.78. The average value of the observations of students at the first and second sessions of 2.42 and 2.92, respectively (Fitria et al., 2019). Then increase in cycle II at the third and fourth sessions for teacher and student observations by $3.71,3.92,3.71$, and 3.85, respectively (Febiartaty et al., 2018).

The improvement in both cycles occurred with the improvement in cycle I and the PBL model application, where students were more active and able to follow the learning process well. Motivation delivered by the teacher at the beginning of learning makes students more eager to participate in learning activities.
Implementation of Problem-based Learning Model to Enhance Students Learning Outcomes in Buffer Solutions Topic

Teachers should manage time and provide maximum motivation. Time management and providing good motivation can help students complete each stage of learning (Rerung et al., 2017). The increase in cognitive student learning outcomes of natural science $11^{\text {th }}$ grade SMA Advent Manokwari in the buffer solution material occurred in cycle I and cycle $\mathrm{II}$, where the percentage of mastery learning in cycle I of $41 \%$ increased in cycle II of $88 \%$ (Juniati \& Widiana, 2017) was shown in Figure 4. Changes were affected the pattern of teacher and student activities in each cycle that increased after reflection and application of PBL learning models. This learning model can create a pleasant learning atmosphere and is not dull for students because they must play an active role in the learning process (Assriyanto et al., 2014).

Percentage of Mastery Learning Outcomes

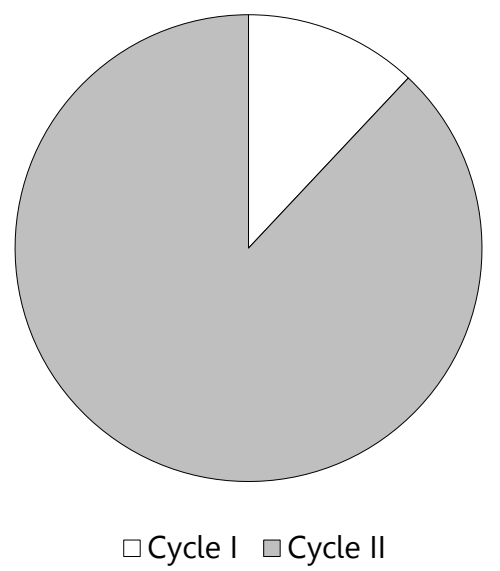

Figure 4. Percentage of Mastery Learning Outcomes

Students are expected to understand and know buffer solutions in everyday life. On the other hand, applying the PBL model can develop their minds and abilities supported by mastery of knowledge to solve problems encountered in everyday life. The main material of the buffer solution was chosen due to its suitable concepts and is easy to apply in everyday life (Trihatmo et al., 2012).

Comparing with research on the application of guided inquiry learning models on the concept of electrolyte and non-electrolyte 
L. V. Letlora, Murtihapsari, C. N. Larasati, A. S. Parubak, A. R. Suparman, P. S. Sarera, T. Aluman \& R. Yogaswara

solutions to improve science process skills implemented, we obtained the average number of student activities during the earning experience increase with each cycle. In the first cycle, the average grade of student activity was 86.4 (very good), and cycle II was 91 (very good). Carry out the worksheets correctly for each cycle so that Guided inquiry learning on the concept of electrolyte and non-electrolyte solutions has increased. The average grade of the first cycle was 70 (good), and the second cycle was 75 (good). Improvement of science process skills of students in cycle I and II with an average grade of 67 (sufficient) and 70 (good) (Dijaya et al., 2018). Furthermore, this compared of the PBL learning model can improve cognitive learning outcomes. This psychomotor can be seen based on percentage increase critical thinking skills. The percentage of critical thinking skills in cycle I was $64 \%$, and cycle II increased to $84 \%$. This can be seen based on a variety of improved aspects such as preparation of tools and materials increasing by $4 \%$, assembling tools and materials increased by $6 \%$, trials increased by $12 \%$, observing experiments increased by $7 \%$, and, and the convey the experiment aspect increases until 8\% (Rerung et al., 2017).

Comparing with research on the percentage of individual passing of the minimum mastery criteria as a whole increase from cycle I to cycle III, which were $69 \%, 81 \%$, and $94 \%$, and the percentage of classical passing of the minimum mastery criteria as a whole increase as well which were $50 \%, 60 \%$, and $80 \%$. (2) there is an increase in teacher and student activity during the learning process. (3) there is an increase in the skills of teachers in managing learning from the sufficient category to the good category. (4) student responses tend to be positive, where $100 \%$ of students say they are happy with learning using Problem-based Learning (PBL), a learning model based on constructivism. Based on this research, applying the Problembased Learning (PBL) can improve the physics learning outcomes of natural science $11^{\text {th }}$ grade students at SMA Negeri 1 Darussalam on the material on Business and Energy (Parasamya et al., 2017).
Implementation of Problem-based Learning Model to Enhance Students Learning Outcomes in Buffer Solutions Topic

Furthermore, the implementation of Problembased Learning can improve learning outcomes in solving story problems in mathematics in $4^{\text {th }}$ grade SD Negeri Suruh 01. The results also improved student learning from the average grade of learning outcomes in the initial conditions 61.85 increased in the first cycle to 69 and in the second cycle it became 80 . The percentage of the number of students who reached Minimum Mastery Criteria increased from the condition initial $44.84 \%$, increased to $69.44 \%$ in the evaluation cycle I and $88.89 \%$ in the evaluation cycle II (Asriningtyas et al., 2018).

\section{Conclusion}

The implementation of PBL model can improve the learning outcomes of natural science 11th grade students of SMA Advent Manokwari on the buffer solutions topic. The PBL model implementation has increased from cycle I to cycle II as demonstrated by average values of 65.36 and 83.66, in which cycle I and cycle II the number of students who have achieved their learning mastery by $41 \%$ and $88 \%$ respectively. The increase in student learning results is $47 \%$. The pedagogical implication used of the Problem-based Learning (PBL) model shows increased results in the activities of teachers, students, and student learning outcomes in chemistry learning on buffer solution material.

\section{References}

Aqib, Z. (2010). Penelitian tindakan kelas untuk guru $S D, S L B, \&$ \&K. Bandung: Yrama Widya.

Ardyanto, Y., Koeswati, H. D., \& Giarti, S. (2018). Model Problem-based Learning (PBL) berbasis media interaktif untuk meningkatkan keterampilan berpikir kritis dan hasil belajar pada sub tema lingkungan tempat tinggalku kelas 4 SD. Pendekar: Jurnal Pendidikan Berkarakter, 1(1), 189-196. https://doi.org/10.31764/pendekar.v1i1. 358 
L. V. Letlora, Murtihapsari, C. N. Larasati, A. S. Parubak, A. R. Suparman, P. S. Sarera, T. Aluman \& R. Yogaswara

Asriningtyas, A. N., Kristin, F., \& Anugraheni, I. (2018). Penerapan Model Pembelajaran Problem-based Learning Untuk Meningkatkan Kemampuan Berpikir Kritis Dan Hasil Belajar Matematika Siswa Kelas 4 SD. JKPM, 5(1).

Assriyanto, K. E., Sukardjo, J. S., \& Saputro, S. (2014). Pengaruh model pembelajaran berbasis masalah melalui metode eksperimen dan inkuiri terbimbing ditinjau dari kreativitas siswa pada materi larutan penyangga di SMAN 2 Sukoharjo tahun ajaran 2013/2014. Jurnal Pendidikan Kimia Universitas Sebelas Maret, 3(3), 89-97. Retrieved from

https://jurnal.fkip.uns.ac.id/index.php/ki mia/article/view/4268

Asyhariyah, S. (2018). Penerapan model pembelajaran Index Card Match (ICM) untuk meningkatan keaktifan belajar siswa mata pelajaran IPS terpadu kelas IX MTs Negeri Gemolong. IJTIMA/YA: Journal of Social Science Teaching, 2(2). https://doi.org/10.21043/ji.v2i2.4301

Badiee, M., Wang, S. C., \& Creswell, J. W. (2012). Designing community-based mixed methods research. Qualitative Strategies for Ethnocultural Research, 41-59. https://doi.org/10.1037/13742003

Beddu, A. T., Sabang, S. M., \& Ningsih, P. (2018). Penerapan model pembelajaran Problem-based Learning (PBL) terhadap hasil belajar siswa SMAN 7 Palu kelas XI pada materi larutan penyangga. Jurnal Akademika Kimia, 7(1), 1-5. http://doi.org/10.22487/j24775185.201 8.v7.i1.10382

Dijaya, A. O., Pitasari, R., \& Kurniasih, S. (2018). Penerapan model pembelajaran inkuiri terbimbing untuk meningkatkan keterampilan proses sains siswa pada konsep larutan elektrolit dan nonelektrolit. JTK (Jurnal Tadris Kimiya),
Implementation of Problem-based Learning Model to Enhance Students Learning Outcomes in Buffer Solutions Topic

$3(2)$, 190-198. https://doi.org/10.15575/jtk.v3i2.3597

Febiartaty, R. A., Parubak, A. S., \& Yogaswara, R. (2018). Penerapan model pembelajaran Project Based Learning (PjBL) untuk meningkatkan hasil belajar peserta didik kelas XI IPA 1 SMA Kristen YABT pada materi sistem koloid. Arfak Chem: Chemistry Education Journal, 8591. Retrieved from https://journalfkipunipa.org/index.php/ accej/article/download/75/50

Fitria, H., Kristiawan, M., \& Rahmat, N. (2019). Upaya meningkatkan kompetensi guru melalui pelatihan penelitian tindakan kelas. Abdimas Unwahas, 4(1), 14-25. https://doi.org/10.31942/abd.v4i1.2690

Hulu, F. (2020). Penerapan model pembelajaran Circuit Learning untuk meningkatkan hasil belajar siswa pada mata pelajaran pendidikan pancasila dan kewarganegaraan di kelas X SMA Negeri 2 Sidua'óri. Jurnal Education and Development, 8(2), 265-270. Retrieved from

https://journal.ipts.ac.id/index.php/ED/a rticle/view/1693

Juniati, N. W., \& Widiana, I. W. (2017). Penerapan model pembelajaran inkuiri untuk meningkatkan hasil belajar IPA. Jurnal Ilmiah Sekolah Dasar, 1(1), 20-29. http://doi.org/10.23887/jisd.v1i1.10126

Larlen. (2012). Upaya meningkatkan minat belajar bahasa indonesia melalui pemanfaatan teknologi pada pembelajaran kelas X SMA Pelita Raya Jambi. Pena: Jurnal Pendidikan Bahasa dan Sastra, 2(2), 49-70. Retrieved from https://www.onlinejournal.unja.ac.id/pena/article/view/143 3

Listiana R., Rosmala, D., \& Fitriana. (2017). Peningkatan prestasi belajar siswa melalui model pembelajaran group Jigsaw pada materi pemanfaatan tekstil untuk benda kerajinan di SMP Negeri 16 
L. V. Letlora, Murtihapsari, C. N. Larasati, A. S. Parubak, A. R. Suparman, P. S. Sarera, T. Aluman \& R. Yogaswara

Takengon. Jurnal Ilmiah Mahasiswa Pendidikan Kesejahteraan Keluarga, 2(2), 1-13. Retrieved from http://www.jim.unsyiah.ac.id/pkk/article /view/5629/pdf

Mustofa, Z., Susilo, H., \& Al-Muhdhar, M., H., I. (2016). Penerapan model pembelajaran Problem-based Learning melalui pendekatan kontekstual berbasis Lesson Study untuk meningkatkan kemampuan memecahkan masalah dan hasil belajar kognitif siswa SMA. Jurnal Pendidikan: Teori, Penelitian, dan Pengembangan, 1(5), 885-889. Retrieved from http://journal.um.ac.id/index.php/jptpp/ article/view/6298/2688

Parasamya, C. E., Wahyuni, A., \& Hamid, A. (2017). Upaya peningkatan hasil belajar fisika siswa melalui penerapan model pembelajaran Problem-based Learning (PBL). Jurnal Ilmiah Mahasiswa (JIM) Pendidikan Fisika, 2(1), 42-49. Retrieved from

http://www.jim.unsyiah.ac.id/pendidika n-fisika/article/view/2145

Pigai, K. Y., Suparman, A. R., \& Larasati, C., N. (2019). Meningkatkan minat dan hasil belajar peserta didik menggunakan model Student Team Achievement Division (STAD) berbantuan papan permainan monopoli pada materi minyak bumi kelas XI IPA SMA Advent Manokwari. Arfak Chem: Chemistry Education Journal, 2(1), 92-98. Retrieved from

https://www.journalfkipunipa.org/index. php/accej/article/view/76

Putri, A. F. A., Utami, B., \& Saputro, A. N. C. (2015). Penerapan model pembelajaran Problem-based Learning disertai eksperimen untuk meningkatkan interaksi sosial dan prestasi belajar siswa pada materi pokok kelarutan dan hasil kali kelarutan di SMA Muhammadiyah 1 Karangayar tahun pelajaran 2014/2015. Jurnal Pendidikan Kimia Universitas Sebelas Maret, 4(4), 27-35. Retrieved
Implementation of Problem-based Learning Model to Enhance Students Learning Outcomes in Buffer Solutions Topic

from

https://jurnal.fkip.uns.ac.id/index.php/ki mia/article/view/6551

Rauf, Y. M., \& Kusmanto, B. (2018). Peningkatan minat dan hasil belajar matematika siswa menggunakan Problem-based Instruction pada materi garis dan sudut siswa kelas VIIB di SMP Taman Dewasa Ibu Pawiyatan Yogyakarta. UNION: Jurnal Ilmiah Pendidikan Matematika, 6(2), 251-258. https://doi.org/10.30738/.v6i2.2112

Rerung, N., Sinon, I. L. S., \& Widyaningsih, S. W. (2017). Penerapan model pembelajaran Problem-based Learning (PBL) untuk meningkatkan hasil belajar peserta didik SMA pada materi usaha dan energi. Jurnal Ilmiah Pendidikan Fisika Al-BiRuNi, 6(1), 47-55. https://doi.org/10.24042/jpifalbiruni.v6i 1.597

Supardi, K. I., \& Putri, I. R. (2010). Pengaruh penggunaan artikel kimia dari internet pada model pembelajaran Creative Problem Solving terhadap hasil belajar kimia siswa SMA. Jurnal Inovasi Pendidikan Kimia, 4(1), 574-581. Retrieved from https://journal.unnes.ac.id/nju/index.ph $\mathrm{p} / \mathrm{JIPK} /$ article/view/1315

Suswati, E., \& Triyanti, M. (2014). Upaya meningkatkan hasil belajar biologi pada materi limbah menggunakan model pembelajaran Cooperatif Scrift di kelas $X$ SMA Negeri 4 Lubuklinggau tahun pelajaran 2013/2014. Jurnal Perspektif Pendidikan, 8(2), 126-134. Retrieved from https://ojs.stkippgrilubuklinggau.ac.id/index.php/JPP/articl e/view/441

Tan, O. S. (2003). Problem-based learning innovation: Using problems to power learning in the 21st century. Singapore: Seng Lee Press. 
L. V. Letlora, Murtihapsari, C. N. Larasati, A. S. Parubak, A. R. Suparman, P. S. Sarera, T. Aluman \& R. Yogaswara

Trihatmo, A., Soeprodjo, \& Widodo, A. T. (2012). Penggunaan model Problembased Learning pada materi larutan penyangga dan hidrolisis. Chemistry in Education, 1(1). 7-13. Retrieved from https://journal.unnes.ac.id/sju/index.ph $\mathrm{p} /$ chemined/article/view/713/772

Utami, T. S., Santi, D., \& Suparman, A. R. (2018). Pengaruh model pembelajaran
Implementation of Problem-based Learning Model to Enhance Students Learning Outcomes in Buffer Solutions Topic

Problem-based Learning ( $\mathrm{PBL}$ ) terhadap hasil belajar kognitif peserta didik kelas XI SMK Negeri 02 Manokwari (studi pada materi pokok konsep laju reaksi) kelompok eksperimen kontrol post test. Arfak Chem: Chemistry Education Journal, 1(1), 21-26. Retrieved from https://journalfkipunipa.org/index.php/ accej/article/view/45 